Provided for non-commercial research and education use. Not for reproduction, distribution or commercial use.

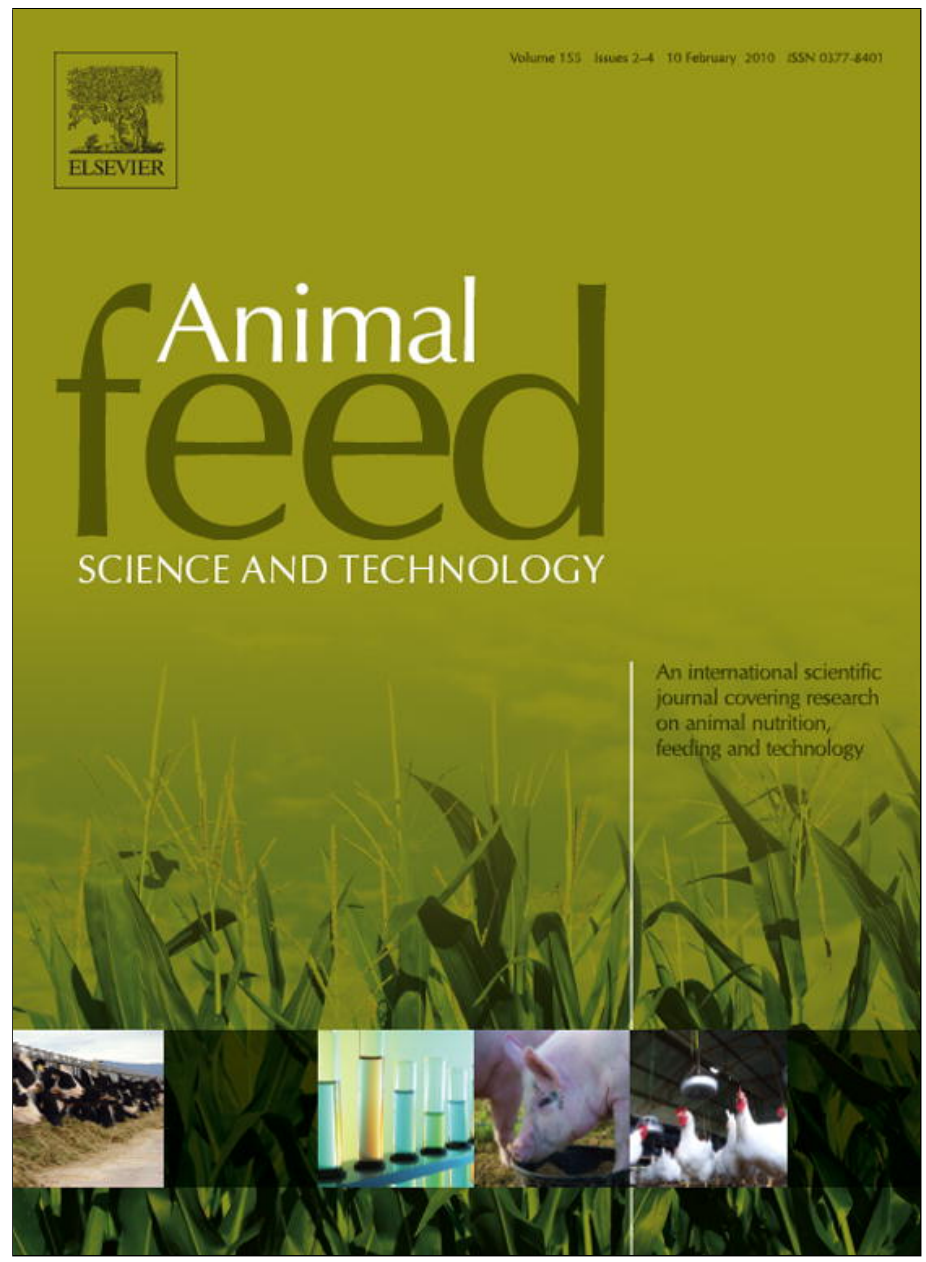

This article appeared in a journal published by Elsevier. The attached copy is furnished to the author for internal non-commercial research and education use, including for instruction at the authors institution and sharing with colleagues.

Other uses, including reproduction and distribution, or selling or licensing copies, or posting to personal, institutional or third party websites are prohibited.

In most cases authors are permitted to post their version of the article (e.g. in Word or Tex form) to their personal website or institutional repository. Authors requiring further information regarding Elsevier's archiving and manuscript policies are encouraged to visit:

http://www.elsevier.com/copyright 
Short communication

\title{
Effect of season on chemical composition and in situ degradability in cows and in adapted and unadapted goats of three Mexican browse species
}

\author{
L.M. Camacho a , R. Rojo ${ }^{\text {a,* }}$, A.Z.M. Salem ${ }^{\text {a,b }}$, F.D. Provenza ${ }^{c}$, G.D. Mendoza ${ }^{\text {, }}$, \\ F. Avilés ${ }^{\mathrm{a}}$, O.D. Montañez-Valdez ${ }^{\mathrm{e}}$ \\ a Centro Universitario UAEM-Temascaltepec, Universidad Autónoma del Estado de México, km 67.5 Carr. \\ Toluca-Tejupilco, Estado de México, C.P. 51300, Mexico \\ b Department of Animal Production, Faculty of Agriculture (El-Shatby), Alexandria University, Egypt \\ c Department of Wildland Resources, Utah State University, Logan, UT 84322-5230, USA \\ d Universidad Autónoma Metropolitana, Unidad Xochimilco, México, Calzada del Hueso 1100, D.F., C.P. 04970, Mexico \\ e Centro Universitario del Sur de la Universidad de Guadalajara (CUSUR-UDG), Mexico
}

\section{A R T I C L E I N F O}

\section{Article history:}

Received 10 September 2008

Received in revised form 16 October 2009

Accepted 4 December 2009

\section{Keywords:}

Browse

Cows

Degradability

Goats

Dry season

Rainy season

\begin{abstract}
A B S T R A C T
Browse foliages from Lysiloma acapulcencis, Quercus laeta and Pithecellobium dulce, native to the subtropical region of southern México, were harvested during the dry season (DS) and rainy season (RS) to determine in situ degradability using ruminal inoculum from fistulated cows as well as goats previously adapted (AG) or not adapted (UG) to browse species fed in their daily diet. Browse leaf samples were incubated in the rumen of each group for $48 \mathrm{~h}$. The crude protein $(\mathrm{CP})$ content of browse was considerably higher in $\mathrm{RS}(P<0.001)$. $P$. dulce had the lowest neutral detergent fiber (NDFom) and acid detergent fiber (ADFom) in the two seasons; $L$. acapulcencis had the highest values and $Q$. laeta values were intermediate, with an overall increase in fiber fractions in DS browse foliage $(P<0.001)$. The lowest in situ degradability values were in $L$. acapulcencis and $Q$. laeta had intermediate values during both seasons. Season of harvest (RS or DS), and ruminal inoculum (cows, UG, and AG) affected $(P<0.001)$ dry matter degradability (DMD), crude protein degradability $(C P D)$ and fiber fractions of browse. Nutrient degradabilities in all species were higher $(P<0.001)$ in DS than RS. Goats previously exposed to these browse species $(A G)$ had higher $(P<0.001)$ in situ degradability of the browse species than cows or goats in UG fed diets without browse. Overall, goats had higher $(P<0.001)$ nutrient in situ degradability than cows. Our results suggest higher potential of these browse species as forages for ruminants during the dry period in semi-arid regions, but goats previously exposed to diets supplemented with the browse species had a better ability to degrade them than cows or goats in UG. P. dulce has the highest potential as a feed protein source in small ruminants during the dry period.
\end{abstract}

(c) 2009 Elsevier B.V. All rights reserved.

Abbreviations: ADFom, acid detergent fiber; AG, adapted goats; AOAC, Association of Official Analytical Chemists; CP, crude protein; DM, dry matter; DS, dry season; GLM, general linear model; NDFom, neutral detergent fiber; OM, organic matter; SAS, Statistical Analyses System; RS, rainy season; CT, condensed tannins; UG, unadapted goats.

* Corresponding author. Tel.: +52 7162665209; fax: +52 7162665209.

E-mail address: dr_rojo70@yahoo.com.mx (R. Rojo). 


\section{Introduction}

The use of browse species as green forage for ruminants is becoming increasingly important in many parts of the tropics, including México. In free-ranging livestock-production systems, browse species are an important supplement to dry season forage shortages, improving both the quantity and quality of pasture. Trees and shrubs are perennials that allow provision of permanent fodder versus herbaceous species which decrease rapidly in quantity and quality after rains. Regular availability of forage from trees and shrubs depends on the diversity of species and their phenological variation in time and space (Grouzis and Sicot, 1980), but they have potential to alleviate feed shortages and nutritional deficiencies during the dry season on smallholder farms. The high quality of some browse in crude protein (CP) content, as well as minerals such as calcium and phosphorus (Paterson et al., 1998), is well appreciated. Tree and shrub leaves can be an important component of small ruminant diets (Papachristou and Nastis, 1996; Salem et al., 2006), and they are important in the nutrition of grazing animals in areas where few, or no, alternative feeds are available (Meuret et al., 1990). However many browse species have secondary compounds that can deter invasion and consumption of their leaves by microbes, insects and herbivorous animals. Tannins are an important class of compounds that can decrease degradability of browse fodders (Salem et al., 2006), but use of tree and shrub leaves by herbivores may be restricted by negative effects on digestion and intake of their generally high levels of several other secondary compounds (Salem, 2005; Salem et al., 2006, 2007).

Goats are effective browsers, that have the ability to utilize woody species and low-quality forages better than cattle and sheep, and can adapt to harsh environments (Silanikove, 2000; Salem et al., 2004). Extensive shrublands of evergreens and small trees, known as garrigue or maquis, that are often high in tannins and other secondary compounds are the basic components of diets of goats in the Mediterranean area (Salem et al., 2006, 2007). Previous studies suggest that progressive adaptation to tannins can be induced in any herbivore species in response to regular feeding of tanniniferous feeds (Pell et al., 2000). Animals adapted to tannins in their diet exhibit changes in rumen microbial populations, and tannin-resistant, or tolerant, bacteria can be isolated particularly from the rumen of animals previously exposed to tanniniferous feeds (Brooker et al., 2000; Odenyo et al., 2003). In México, there is limited information on the nutritive value of tree shrubs fed to livestock (Ramirez et al., 2000; Cerrillo and Juárez, 2004). Our aim was thus to investigate impacts of growing season on ruminal in situ degradability of some tree foliages using rumen fluid from goats (adapted or unadapted to eating tree foliage) and cows under the southern subtropical conditions in México.

\section{Materials and methods}

\subsection{Area of sample collection}

Tree fodder species were collected from the South of Estado de México (Tejupilco) and the related metabolic work and laboratory analyses were completed at the Centro Universitario UAEM Temascaltepec located in the municipality of Temascaltepec de González Estado de México. Geographically, this is located at $19^{\circ} 02^{\prime} 04^{\prime \prime}$ north latitude and $100^{\circ} 02^{\prime} 14^{\prime \prime}$ west longitude at an elevation of 1720 masl. The climate is moderately humid with an average temperature of $15-18^{\circ} \mathrm{C}$ and annual rainfall of 950-1000 $\mathrm{mm}$ (García, 1987).

\subsection{Browse species}

We sampled a mixture of young and mature leaves from three browse species - Tepehuaje (Lysiloma acapulcencis), Encino prieto (Quercus laeta) and Pinzan (Pithecellobium dulce) - that contain different levels of CT (high, medium, and low) from several locations in the South of Estado de México. Plant samples $(\sim 5 \mathrm{~kg})$ were randomly collected up to a height of $1.5 \mathrm{~m}$ from at least 7 trees for each browse species during the rainy (i.e., August/September, 2006) and dry (April/May, 2007) seasons. Samples of each species were pooled to three samples and air dried in the shade to minimize changes in tannins content and activity (Makkar and Singh, 1991; Yousef and Rouzbehan, 2008; Robinson et al., 2006).

\subsection{Analytical methods}

Fresh samples were dried at $45^{\circ} \mathrm{C}$ for $48 \mathrm{~h}$ for moisture determination and ground in a Willey-mill to pass a $1 \mathrm{~mm}$ screen. Ground samples were analyzed for dry matter (DM) by drying at $105^{\circ} \mathrm{C}$ for $24 \mathrm{~h}$ in a forced air oven. Ash content was measured after igniting samples in a muffle furnace at $550^{\circ} \mathrm{C}$ for $4 \mathrm{~h}$. The $\mathrm{CP}$ was determined by the Kjeldahl method (AOAC, 1990; ID 954.01). Neutral detergent fiber (NDFom) and acid detergent fiber (ADFom) were determined by the methods of Van Soest et al. (1991) with NDFom assayed without use of an alpha amylase, but with sodium sulfite. Both NDFom and ADFom are expressed without residual ash. Total condensed tannins (TCT) were assayed using the butanol-HCL method (Terrill et al., 1992), modified by López et al. (2004), as internal standards using L. acapulsencis. Analyses of the free, protein-bound and fiber-bound CT were conducted, according to the method of Porter et al. (1986), The purification was performed with Sephadex LH-20 as described by Asquith and Butler (1985) with modifications by Hagerman (1991). Tannin results were the starting point for categorizing the species in three types: high (L. acapulcencis), medium (Q. laeta) and low (P. dulce) tannin concentrations (Table 1). 
Table 1

Chemical composition and condensed tannins ( $\mathrm{g} / \mathrm{kg} \mathrm{DM})$ of the leaves of three species of browse tree during the rainy and dry seasons.

\begin{tabular}{|c|c|c|c|c|c|c|c|c|c|c|}
\hline \multirow{2}{*}{$\begin{array}{l}\text { Season (S) } \\
\text { Browse species (B) }\end{array}$} & \multicolumn{3}{|l|}{ Rainy } & \multicolumn{3}{|l|}{ Dry } & \multirow[t]{2}{*}{ Sed } & \multicolumn{3}{|l|}{ Pvalue } \\
\hline & L. acapulcencis & Q. laeta & P. dulce & L. acapulcencis & Q. laeta & P. dulce & & $\mathrm{S}$ & B & $\mathrm{S} \times \mathrm{B}$ \\
\hline OM & $945.9^{b}$ & $950.4^{\mathrm{a}}$ & $909.5^{d}$ & $941.5^{c}$ & $905.6^{e}$ & $862.1^{f}$ & 7.98 & $<0.001$ & $<0.001$ & $<0.001$ \\
\hline $\mathrm{CP}$ & $177.0^{c}$ & $94.1^{\mathrm{e}}$ & $261.5^{\mathrm{a}}$ & $110.6^{d}$ & $84.7^{f}$ & $187.8^{\mathrm{b}}$ & 9.21 & $<0.001$ & $<0.001$ & $<0.001$ \\
\hline NDFom & $607.3^{a}$ & $584.1^{\mathrm{ab}}$ & $495.8^{c}$ & $545.0^{\mathrm{b}}$ & $408.3^{d}$ & $357.3^{e}$ & 2.06 & $<0.001$ & $<0.001$ & $<0.001$ \\
\hline ADFom & $500.8^{a}$ & $411.8^{\mathrm{b}}$ & $365.7^{c}$ & $478.6^{a}$ & $249.8^{d}$ & $274.7^{d}$ & 2.31 & $<0.001$ & $<0.001$ & $<0.001$ \\
\hline Free-CT & $116.3^{a}$ & $64.2^{\mathrm{cd}}$ & $36.6^{d}$ & $101.6^{\mathrm{ab}}$ & $80.2^{\mathrm{bc}}$ & $68.3^{\mathrm{cd}}$ & 6.71 & 0.077 & $<0.001$ & 0.016 \\
\hline PCT & $67.8^{\mathrm{a}}$ & $23.0^{c}$ & $21.8^{\mathrm{c}}$ & $55.8^{\mathrm{b}}$ & $26.3^{c}$ & $21.1^{\mathrm{c}}$ & 4.57 & 0.067 & $<0.001$ & 0.005 \\
\hline FCT & $3.7^{b}$ & $2.7^{c}$ & $4.1^{\mathrm{ab}}$ & $2.8^{c}$ & $2.5^{c}$ & $4.7^{\mathrm{a}}$ & 0.21 & 0.190 & $<0.001$ & 0.003 \\
\hline TCT & $187.8^{\mathrm{a}}$ & $89.9^{\mathrm{bc}}$ & $62.6^{c}$ & 160.2 & $109.0^{\mathrm{b}}$ & $94.1^{\mathrm{bc}}$ & 10.77 & 0.229 & $<0.001$ & 0.004 \\
\hline
\end{tabular}

Means with different superscripts within a row differ $(P<0.05)$ between season of harvest of browse species. OM; organic matter, CP; crude protein, NDFom; neutral detergent fiber, ADFom; acid detergent fiber, Free-CT: free condensed tannins; PCT: protein-bound condensed tannins; FCT: fiber-bound condensed tannins; TCT: total condensed tannins. Sed: standard error of the difference.

\subsection{Animals and diets}

Two brown Swiss American cows $(530 \pm 5 \mathrm{~kg}$ ) and 4 male Criollo $\times$ Nubia goats ( $34 \pm 4 \mathrm{~kg}$ body weight) were used for sample incubation. Animals were fitted with permanent ruminal cannula about 150 days before the ruminal incubations. The 2 cows and 2 goats (unadapted goats; UG) were fed forage:concentrate (80:20; DM basis) diets. The forage contained a mixture of alfalfa hay $(400 \mathrm{~g} / \mathrm{kg})$, corn silage $(400 \mathrm{~g} / \mathrm{kg})$ and corn straw $(200 \mathrm{~g} / \mathrm{kg})$ with a concentrate mixture $(220 \mathrm{~g} / \mathrm{kg} \mathrm{CP})$, containing ground sorghum (380 g/ kg), corn (380 g/ kg), soybean (120 g/ kg), molasses ( $80 \mathrm{~g} / \mathrm{kg})$, urea (20 g/kg) and minerals $(20 \mathrm{~g} / \mathrm{kg})$. The other 2 goats were fed the same concentrate mixture offered to the cows and UG, but the forage proportion was alfalfa hay $(300 \mathrm{~g} / \mathrm{kg}$ ) and browse species $(700 \mathrm{~g} / \mathrm{kg}$ ) composed of $128 \mathrm{~g} / \mathrm{kg}$ P. dulce, $198 \mathrm{~g} / \mathrm{kg}$ Quercus sp., $261 \mathrm{~g} / \mathrm{kg} \mathrm{Q}$. laeta, $413 \mathrm{~g} / \mathrm{kg}$ L. acapulcencis. The AG animals were fed this diet for 100 days before sample incubation. All animal groups were fed twice daily at 07:00 and 16:00 h. All animals had free access to vitamin-mineral mixture and clean water.

\subsection{In situ degradability}

In situ degradability was measured by the method of Ørskov et al. (1980) with nylon bags $(5 \mathrm{~cm} \times 10 \mathrm{~cm})$ with a pore size of $35 \mu \mathrm{m}$ diameter. Samples of the three browse species with different contents (high, medium, and low) of CT, collected during the rainy and dry seasons, were ground to pass a $1 \mathrm{~mm}$ screen in a Wiley mill. Samples, $2.5 \mathrm{~g}$ DM/bag, were incubated in the rumen of each fistulated animal for $48 \mathrm{~h}$. Three bags, of the same browse species, were introduced into the rumen of each animal species (cows, UG, and AG) before the morning feeding. The incubation was repeated with the same fistulated animal. After removal of all bags simultaneously from the rumen, bags were washed with tap water until the water was clear. They were then dried in a forced air oven at $65^{\circ} \mathrm{C}$ and weighed to determine DM loss. The N and fiber fractions (NDFom and ADFom) were determined in residues to calculate the degradability.

\subsection{Statistical model and analysis}

Data for the chemical assays were analyzed using the general linear model (GLM) procedure in SAS (2002) for a completely randomized design with 2 seasons (rainy and dry) $\times 3$ browse species in a factorial arrangement with 3 repetitions (pooled samples) (Steel and Torrie, 1980). Means were tested using a least square means test (LSMEANS) with the statistical model:

$$
Y_{i k}=\mu+S_{j}+B_{k}+S_{j} \times B_{k}+E_{j k}
$$

where $Y_{i k}$ represents response variables (chemical composition) for the two seasons $(j)$ for each of the three browse species $(k) ; \mu=$ general mean; $S_{j}=$ effect of $j$-season; $B_{k}=$ effect of $k$-browse species; $S_{j} \times B_{k}=$ interaction of the $j$ season with $k$ browse species; $E_{i k}=$ the error term $-\mathrm{NI}\left(0, \sigma^{2}\right)$.

Data for in situ degradability were analyzed using a randomized complete block design with 2 seasons (rainy and dry) $\times 3$ sources of inoculum (cows, UG, and AG) $\times 3$ browse species in factorial arrangement with 3 repetitions (Steel and Torrie, 1980). The mixed model was:

$$
Y_{j k l}=\mu+S_{j}+\mathrm{TI}_{k}+\mathrm{Sp}_{l}+\beta_{n}+S_{j} \times \mathrm{TI}_{k} \times \mathrm{Sp}_{l}+E_{j k l}
$$

where $Y_{j k l}$ represents response variables (degradability of DM, CP, NDF and ADF) for the same season $(j)$, source of ruminal inoculum $(k)$, and browse species $(l) ; \mu$ general mean; $S_{j}=$ effect of $j$ season; $\mathrm{TI}_{k}=$ effect of $k$-type of ruminal inoculum; $\mathrm{Sp}_{l}=$ effect of $l$ browse species; $\beta_{n}=$ effect of $n$-block (repeated incubation); $S_{j} \times \mathrm{TI}_{k} \times \mathrm{Sp}_{l}=$ interaction of the $j$ season with $k$ type of ruminal inoculum and $l$-browse species; $E_{j k l}=$ the error term $-\mathrm{NI}\left(0, \sigma^{2}\right)$.

Differences among means with $P<0.05$, determined using a least square means test (LSMEANS), were accepted as representing statistically significant differences (Steel and Torrie, 1980). 
Table 2

In situ degradability (g/kg) of dry matter (DMD), crude protein (CPD), neutral detergent fiber (NDFD) and acid detergent fiber (ADFD) of some browse tree foliages after $48 \mathrm{~h}$ of incubation in the rumen of cows as well as unadapted (UG) and adapted (AG) goats during the rainy and dry seasons.

\begin{tabular}{|c|c|c|c|c|c|c|}
\hline Season & Inoculum & Browse & DMD & CPD & NDFD & ADFD \\
\hline \multirow[t]{9}{*}{ Rainy } & Cows & L. acapulcencis & $241.6^{\mathrm{k}}$ & $21.7^{1}$ & $61.1^{\mathrm{ij}}$ & $109.3^{\text {hi }}$ \\
\hline & & Q. laeta & $331.8^{\mathrm{gh}}$ & $131.4^{\mathrm{hi}}$ & $142.0^{\mathrm{gf}}$ & $230.7^{\mathrm{ef}}$ \\
\hline & & P. dulce & $544.3^{c}$ & $584.6^{\mathrm{bc}}$ & $308.6^{b c}$ & $303.6^{\mathrm{cd}}$ \\
\hline & UG & L. acapulcencis & $273.1^{\mathrm{j}}$ & $19.9^{1}$ & $88.0^{\text {hi }}$ & $121.2^{\mathrm{hi}}$ \\
\hline & & Q. laeta & $369.5^{\mathrm{ef}}$ & $176.0^{\text {hg }}$ & $162.5^{\mathrm{ef}}$ & $247.6^{\mathrm{ef}}$ \\
\hline & & P. dulce & $547.8^{c}$ & $581.9^{\mathrm{bc}}$ & $332.4^{\mathrm{ab}}$ & $374.7^{\mathrm{ab}}$ \\
\hline & AG & L. acapulcencis & $281.9^{j}$ & $108.5^{\mathrm{ij}}$ & $109.2^{\text {hig }}$ & $144.3^{\text {gh }}$ \\
\hline & & Q. laeta & $389.5^{e}$ & $226.4^{\mathrm{f}}$ & $163.7^{\mathrm{ef}}$ & $198.5^{\mathrm{fg}}$ \\
\hline & & P. dulce & $514.6^{d}$ & $563.1^{c}$ & $273.8^{c}$ & $340.2^{\mathrm{bc}}$ \\
\hline \multirow[t]{9}{*}{ Dry } & Cows & L. acapulcencis & $296.7^{\mathrm{ij}}$ & $59.0^{\mathrm{kl}}$ & $38.1^{\mathrm{j}}$ & $61.6^{\mathrm{i}}$ \\
\hline & & Q. laeta & $499.9^{d}$ & $214.0^{\mathrm{if}}$ & $121.1^{\mathrm{gfh}}$ & $112.5^{\mathrm{hi}}$ \\
\hline & & P. dulce & $596.9^{b}$ & $625.4^{b}$ & $214.7^{d}$ & $291.5^{\text {cde }}$ \\
\hline & UG & L. acapulcencis & $310.7^{\text {ih }}$ & $71.2^{\mathrm{jk}}$ & 77.6 $6^{\text {hij }}$ & $101.5^{\mathrm{hi}}$ \\
\hline & & Q. laeta & $551.7^{c}$ & $304.8^{\mathrm{e}}$ & $217.0^{\mathrm{d}}$ & $143.9^{g h}$ \\
\hline & & P. dulce & $668.9^{a}$ & $730.9^{a}$ & $366.2^{\mathrm{a}}$ & $404.1^{a}$ \\
\hline & AG & L. acapulcencis & $344.7^{g f}$ & $152.1^{\text {hi }}$ & $116.1^{\mathrm{gfh}}$ & $121.7^{\mathrm{hi}}$ \\
\hline & & Q. laeta & $558.6^{c}$ & $371.6^{d}$ & $197.7^{\text {ed }}$ & $105.2^{\mathrm{hi}}$ \\
\hline & & P. dulce & $652.8^{\mathrm{a}}$ & $738.5^{a}$ & $336.2^{\mathrm{ab}}$ & $381.8^{\mathrm{ab}}$ \\
\hline \multirow[t]{3}{*}{ Sed } & 5.61 & 9.73 & 9.84 & 10.92 & & \\
\hline & & \multicolumn{2}{|l|}{$P$ value } & & & \\
\hline & & DMD & $\mathrm{CPD}$ & \multicolumn{2}{|r|}{ NDFD } & ADFD \\
\hline \multicolumn{2}{|c|}{ Season } & $<0.001$ & $<0.001$ & \multicolumn{2}{|r|}{0.232} & $<0.001$ \\
\hline \multicolumn{2}{|c|}{ Inoculum } & $<0.001$ & $<0.001$ & \multicolumn{2}{|r|}{$<0.001$} & $<0.001$ \\
\hline \multicolumn{2}{|c|}{ Browse } & $<0.001$ & $<0.001$ & \multicolumn{2}{|r|}{$<0.001$} & $<0.001$ \\
\hline \multicolumn{2}{|c|}{ Season $\times$ inoculum $\times$ browse } & $<0.001$ & $<0.001$ & \multicolumn{2}{|r|}{$<0.001$} & $<0.001$ \\
\hline
\end{tabular}

UG: unadapted goats; AG: adapted goats. Means within a column with different superscripts differ $(P<0.05)$.

\section{Results}

The CP content of the browse species ranged from $85 \mathrm{~g} / \mathrm{kg}$ (DS: dry season) and $94 \mathrm{~g} / \mathrm{kg}$ (RS: rainy season) for $Q$. Laeta to $262 \mathrm{~g} / \mathrm{kg}$ DM for P. dulce in the RS (Table 1). Overall, CP content of browse species was considerably higher in the rainy season $(P<0.001)$. P. dulce had the lowest NDFom and ADFom in the two seasons, L. acapulcencis had the highest values, and Q. laeta values were intermediate with an overall increase in fiber fractions in the rainy season $(P<0.001)$. The browse species differed in CT contents $(P<0.01-$ Table 1$)$. Overall, free-CT values were lower in $Q$. Laeta and $P$. dulce in the RS than in the DS, except $L$. acapulcencis had the opposite though non-significant effect. Soluble or free-CT fraction varied from 36.6 in $P$. dulce to $116.3 \mathrm{~g} / \mathrm{kg} \mathrm{DM}$ in L. acapulcencis during the RS. The protein-bound CT (PCT) fraction had the same trend of free-CT content in the tree species and varied $(P<0.05)$ from $21 \mathrm{~g} / \mathrm{kg}$ in $P$. dulce (DS) to $67.8 \mathrm{~g} / \mathrm{kg}$ DM in L. acapulcencis (RS). PCT was not different between $Q$. Laeta and $P$. dulce in the two seasons.

Season of harvest (RS or DS), and ruminal inoculum (cows, goats (UG or AG)) both affected $(P<0.001)$ DMD, CPD and fiber fractions of the browse (Table 2). Nutrient in situ degradability of all browse species was higher $(P<0.001)$ during the DS than the RS. In situ degradability of browse species in goats previously exposed to the browse species (AG) was higher $(P<0.001)$ than in cows or UG fed diets without browse. Overall, goats had higher $(P<0.001)$ nutrient degradability of browse foliage than cows. However, $P$. dulce had the highest $(P<0.001)$ in situ degradability values, while the lowest values were for L. acapulcencis with $Q$. laeta intermediate during the two growing seasons.

\section{Discussion}

\subsection{Chemical composition and condensed tannins}

Lower levels of CP in browse during the DS versus the RS (Table 1) are consistent with other studies, which indicate that the minimum CP content of fodder tree leaves in the DS is more than twice that of grasses in the RS (Evitayani et al., 2004). Importantly, the CP content of browse species remained relatively high in $P$. dulce and L. acapulcencis during the DS, suggesting the possibility that leaves may be used as a DS fodder and feed supplement to low-quality diets. However, high secondary compound levels in L. acapulcencis may prevent its use if the nutrients cannot be digested and utilized. The higher 
CP content in P. dulce, with its low CT during both seasons, suggests that it may be better quality forage for ruminants than the other browse species.

The CT content of browse species increased during the DS versus the RS, likely due to hydric stress in DS, activating enzymatic system phenylalanine ammonia-lyase (PAL) (Hidalgo, 2002) higher DS temperatures a finding consistent with those of Cabiddu et al. (2000) and Salem et al. (2006) for various browse species. Decreased concentrations of CT in browse leaves during the RS season may be due to the plant allocating more soluble carbohydrates to growth and reproduction than to producing tannins (Skogsmyr and Fagerstrom, 1992). This dilution effect during the RS may also explain the lower concentrations of fiber during the DS. Such seasonal variation in response to climatic and physiological changes in browse plants induces changes in chemical composition and, in particular, in concentrations of secondary compounds such as tannins (Salem, 2005; Salem et al., 2006). These differences determine the value of browse plant foliages as forages for ruminants.

\subsection{Ruminal digestibility of browse species}

Lower in situ degradability of browse species during the DS versus the humid RS in cows and goats could be due to the effects of CT on available $\mathrm{N}$ in leaves, which could reduce rumen ammonia concentrations and microbial growth (Salem et al., 2007). Cross-linkages of lignin to hemicellulose, polysaccharides and proteins may also depress digestibility (Van Soest, 1994). In the current study, the lignin content of RS browse was likely high, as suggested by the positive relationship between NDFom and ADFom in the studies of Frutos et al. (2002), and this could explain the lower of DM and NDF degradability of browse during the DS.

Differences between cows and goats in ruminal in situ degradability were probably due to differences in rumen microbial populations that affect the kinetics of rumen fermentation. In a comparison of sheep and goats, Salem et al. (2004) concluded that differences between sheep and goats in dentition, chewing/eating behaviour, gut physiology, compartment dimensions and retention time all influence gut microflora. Cone et al. (2002) compared rumen fluid from cows and sheep fed a similar diet, and reported that the volume of gas produced was lower with rumen fluid from sheep, although there was a good relationship between volumes of gas produced by the two sources of inocula. Bueno et al. (1999) compared bovine and ovine rumen fluid inocula adjusted to provide the same microbial mass and concluded that the two sources were comparable under tropical conditions.

Animals that regularly consume tanniniferous feedstuffs adapt to minimize the detrimental effects of tannins. In our study, goats in AG, exposed for 3 months to diets containing $560 \mathrm{~g} / \mathrm{kg}$ of a mixture of $P$. dulce, Q. laeta and L. acapulcencis, had higher nutrient in situ degradability than unadapted goats (UG) or cows. Wiryawan et al. (2000) observed that in vitro digestibility of Caliandra foliage was lowest in rumen fluid from goats fed grass, and increased when they were fed Caliandra for 3 months before the digestibility determinations. Similar results were reported by Tjakradidjaja et al. (2000) who observed that browse from high-tannin species (Acacia or Caliandra) were digested better by goats adapted to consuming high-tannin feedstuffs.

In goats, in situ degradability of browse species was higher in AG than in UG goats, which is consistent with McSweeney et al. (2001) who reported that within the same animal species responses to tanniniferous diets depend largely on the physiological capacity of the animals to adapt to the high-tannin diets. Mlambo et al. (2007) found that in vitro digestibility and fermentation kinetics of tannin-containing substrates improved when rumen fluid was obtained from goats fed a mixture of tannin-containing tree fruits (adapted rumen fluid). This is consistent with our finding that adapted goats had enhanced fermentative activity in the rumen to degrade high-tannin substrates, but this benefit was less evident with feedstuffs with lower concentrations of tannins.

Ruminants have a higher tolerance of tannins than non-ruminants (Smith et al., 2001), due to extra mastication, large amounts of saliva and rumen fermentation (Salem et al., 2001), and our results were likely due in part to acclimatization of microbial populations in the rumen. Odenyo and Osuji (1988) identified some tannin-tolerant ruminal bacterial strains from enriched cultures of rumen microflora of goats to establish a medium containing high concentrations of crude tannin extract or tannic acid. A strain of the anaerobe Selenomonas ruminantium, subspecies ruminantium, capable of growing on tannic acid or condensed tannin as a sole energy source, has been isolated from ruminal contents of feral goats browsing tannin-rich foliage (Skene and Brooker, 1995). Transferring these micro-organisms from feral goats to domestic goats and sheep fed tannin-rich foliage increased feed intake and $\mathrm{N}$ retention in inoculated versus uninoculated goats. Inoculation also improved $\mathrm{N}$ digestibility and reduced the rate of live weight loss in sheep and domestic goats (Miller et al., 1995).

\section{Conclusions}

Higher nutritive value of browse species during the dry season for cows and goats could explain the great importance of those species in the nutrition of grazing ruminants in semi-arid regions of Mexico. $P$. dulce has potential to be used as protein source for sheep and goats during the dry season. Goats previously exposed to diets supplemented with the browse species were better able to degrade the browse species than goats fed diets not supplemented with browse species, which likely enables adapted goats to better use browse scrubland (Salem et al., 2006). Our results are consistent with the hypothesis that microbial populations in the rumen of goats fed a diet supplemented with the same browse species may evolve to become resistant to secondary compounds, in particularly condensed tannins, thereby becoming superior at degrading feedstuffs rich in condensed tannins. 


\section{Acknowledgements}

This work was undertaken with funds from the Universidad Autónoma del Estado de México (project UAEM 2400/2006U). Our gratitude also to the Mexican National Council for Science and Technology (Consejo Nacional de Ciencia y TecnologíaCONACYT) for the grant received by Luis Miguel Camacho Díaz.

\section{References}

AOAC, 1990. Official Methods of Analysis. Association of Analytical Chemists, Arlington, VA.

Asquith, T.N., Butler, L.G., 1985. Use of dye-labeled protein as spectrophotometric assay for protein precipitants such as tannin. J. Chem. Ecol. 11, 1535-1544. Brooker, J.D., OǐDonovan, L.A., Skene, I., Sellick, G., 2000. Mechanisms of tannin resistance and detoxification in the rumen. In: Brooker, J.D. (Ed.), Tannins in Livestock, Human Nutrition, pp. 117-122, ACIAR Proceeding No. 92, Australia.

Bueno, I.C.S., Abdalla, A.l., Cabral Filho, S.L.S., Vitta, D.M.S.S., Owen, E., Mauricio, R.M., Givens, D.I., Sutton, J.D., Mould, F.L., 1999. Comparison of inocula from sheep and cattle for the in vitro gas production technique under tropical conditions. Proc. Br. Soc. Anim. Sci., 151.

Cabiddu, A., Decandia, M., Sitiza, M., Molle, G., 2000. A note on the chemical composition and tannin content of some Mediterranean shrubs browsed by Sarda goats. OPTIONS Méditerranéennes 52, 175-178.

Cerrillo, M.A., Juárez, R.A.S., 2004. In vitro gas production parameters in cacti and tree species commonly consumed by grazing goats in a semiarid region of North Mexico. Livest. Res. Rural Dev. 16, 4.

Cone, J.W., van Gelder, A.H., Bachmann, H., 2002. Influence of inoculum source on gas production profiles. Anim. Feed Sci. Technol. 99, 221-231.

Evitayani, Warly, L., Fariani, A., Ichinohe, T., Abdulrazak, S.A., Fujihara, T., 2004. Comparative rumen degradability of some legumes forages between wet and dry seasons in west Sumatra, Indonesia. Asian-Aust. J. Anim. Sci. 17, 1107-1111.

Frutos, P., Hervás, G., Ramos, G., Giráldez, F.J., Mantecon, A.R., 2002. Condensed tannin content of several shrub species from a mountain area in northern Spain, and its relationship to various indicators of nutritive value. Anim. Feed Sci. Technol. 95, 215-226.

García, E., 1987. In: Cuarta, J.D. (Ed.), Modificaciones al sistema de clasificación climática de Koopen para adaptarlo a las condiciones de la República Mexicana. Universidad Nacional Autónoma de México, pp. 65-79.

Grouzis, M., Sicot, M., 1980. A method for the phenological study of browse populations in the Sahel: the influence of some ecological factors. In: Le Houerou, H.N. (Ed.), Browse in Africa. ILCA, Addis Ababa, pp. 233-240.

Hagerman, A.E., 1991. Tannin Analysis. Miami University, Oxford, OH, USA.

Hidalgo, T.J., 2002. Tratado de enología. Mundi-Prensa, Spain, p. 1423.

López, J., Tejada, I., Vázquez, C., Garza, J.d.D., Shimada, A., 2004. Condensed tannins in humid tropical fodder crops and their in vitro biological activity part 1. J. Sci. Food Agric. 84, 295-299.

Makkar, H.P.S., Singh, B., 1991. Distribution of condensed tannins (proanthocyanidins) in various fractions of young and mature leaves of some oak species. Anim. Feed Sci. Technol. 32, 253-260.

Meuret, M., Boza, J., Narjisse, N., Nastis, A., 1990. Evaluation and utilization of rangeland feeds by goats. In: Morand-Fehr, P. (Ed.), Goat Nutrition. PUDOC, Wageningen, The Netherlands, pp. 161-170.

McSweeney, C.S., Palmer, B., Bunch, R., Krause, D.O., 2001. Effect of the tropical forage Calliandra on microbial protein synthesis and ecology in the rumen. Appl. Environ. Microbiol. 90, 78-88.

Miller, S.M., Brooker, J.D., Blackall, L.L., 1995. A feral goat rumen fluid inoculum improves nitrogen retention in sheep consuming a mulga (Acacia aneura) diet. Aust. J. Agric. Res. 46, 1545-1553.

Mlambo, V., Sikosana, J.L.N., Mould, F.L., Smith, T., Owen, E., Mueller-Harvey, I., 2007. The effectiveness of adapted rumen fluid versus PEG to ferment tannin-containing substrates in vitro. Anim. Feed Sci. Technol. 136, 128-136.

Odenyo, A.A., Osuji, P.O., 1988. Tannin-tolerant ruminal bacteria from East African ruminants. Can. J. Microbiol. 44, 905-909.

Odenyo, A.A., Osuji, P.O., Reed, J.D., Smith, A.H., Mackie, R.I., McSweeney, C.S., Hanson, J., 2003. Acacia angustissima: its anti-nutrients constituents, toxicity and possible mechanisms to alleviate the toxicity-a short review. Agroforest. Syst. 59, 141-147.

Ørskov, E.R., DeB Hovell, F.D., Mould, F., 1980. The use of the nylon bag technique for the evaluation of feedstuffs. Trop. Anim. Prod. 53, $195-213$.

Papachristou, T.G., Nastis, A.S., 1996. Influence of deciduous broadleaved woody species in goat nutrition during the dry season in Northern Greece. Small Rumin. Res. 20, 15-22.

Paterson, R.T., Karanja, G.M., Roothaert, R.L., Nyaata, O.Z., Kariuki, I.W., 1998. A review of tree fodder production and utilization within smallholder agroforestry systems in Kenya. Agroforestry Systems 41, 181-199.

Porter, L.W., Hrstich, L.N., Chan, B.G., 1986. The conversion of proanthocyanidins and prodelphinidins to cyaniding and delphinidin. Phytochemistry 25 , 223-230.

Pell, A.N., Woolston, T.K., Nelson, K.E., Schofield, P., 2000. Tannins: biological activity and bacterial tolerance. In: Brooker, J.D. (Ed.), Tannins in Livestock and Human Nutrition. ACIAR, Adelaide, Australia, pp. 121-126.

Ramirez, R.G., Neira-Morales, R.R., Torres-Noriega, J.A., Mercado-Santos, A.C., 2000. Seasonal variation of chemical composition and crude protein digestibility in seven shrubs of NE Mexico. Phyton 68, 77-82.

Robinson, P.H., Wiseman, J., Udén, P., Mateos, G., 2006. Some experimental design and statistical criteria for analysis of studies in manuscripts submitted for consideration for publication. Anim. Feed Sci. Technol. 129, 1-11.

Salem, A.Z.M., 2005. Impact of season of harvest on in vitro gas production and dry matter degradability of Acacia saligna leaves with inoculum from three ruminant species. Anim. Feed Sci. Technol. 123-124, 67-79.

Salem, A.Z.M., González, J.S., López, S., Ranilla, M.J., 2001. Evolución de la respuesta en la producción unilateral de saliva parotidea a la inclusión de quebracho en la dieta en ganado ovino y caprino. In: En: Asociación Interprofesional para el Desarrollo Agrario (AIDA) IX Jornadas sobre producción Animal, Tomo I, 25-27 de abril, Zaragoza, Spain, pp. 322-324.

Salem, A.Z.M., González, J.S., López, S., Ranilla, M.J., 2004. Feeding behaviour patterns and water intake in sheep and goats fed alfalfa hay treated with quebracho. OPTIONS Méditerranéennes 59, 215-219.

Salem, A.Z.M., Salem, M.Z.M., El-Adawy, M.M., Robinson, P.H., 2006. Nutritive evaluations of some browse tree foliages during the dry season: secondary compounds, feed intake and in vivo digestibility in sheep and goats. Anim. Feed Sci. Technol. 127, 251-267.

Salem, A.Z.M., Robinson, P.H., El-Adawy, M.M., Hassan, A.A., 2007. In vitro fermentation and microbial protein synthesis of some browse tree leaves with or without addition of polyethylene glycol. Anim. Feed Sci. Technol. 138, 318-330.

SAS Institute, 2002. SAS User's Guide: Statistics. Ver 9.0. SAS Institute, Cary, N.C., USA, 956 p.

Silanikove, N., 2000. The physiological basis of adaptation in goats to harsh environments. Small Rum. Res. 35, $181-193$.

Smith, A.H., Odenyo, A.A., Osuji, P.O., Wallig, M.A., Kandil, F.E., Seigler, D.S., Mackie, R.I., 2001. Evaluation of toxicity of Acacia angustissima in a rat bioassay. Anim. Feed Sci. Technol. 91, 41-57.

Skene, I.K., Brooker, J.D., 1995. Characterization of tannin acylhydrolase activity in the ruminal bacterium Selenomonas ruminantium. Anaerobe 1, $321-327$. Skogsmyr, I., Fagerstrom, T., 1992. The cost of anti-herbivory defense: an evaluation of some ecological and physiological factors. Okios 64, 451-457.

Steel, R.G.D., Torrie, J.H., 1980. Principles and Procedures of Statistics, 2nd ed. McGraw-Hill International, New York, NY, USA, p. 633.

Terrill, T.H., Rowan, A.M., Douglas, G.B., Barry, T.N., 1992. Determination of extractable and bound condensed tannin concentrations in forage plants, protein concentrate meals and cereal grains. J. Sci. Food Agric. 58, 321-329. 
Tjakradidjaja, A.S., Brooker, J.D., Bottema, C.D.K., 2000. Characterisation of tannin-resistant bacteria from the rumen fluid of feral goats and camels with restriction analysis of amplified 16S rDNA. In: Brooker, J.D. (Ed.), Tannins in Livestock and Human Nutrition. ACIAR, Adelaide, Australia, pp. 161-165.

Van Soest, P.J., 1994. Nutritional Ecology of the Ruminant. Cornell University Press, Ithaca, NY, USA.

Van Soest, P.J., Robertson, J.B., Lewis, B.A., 1991. Methods for dietary fibre, neutral detergent fibre, and non-starch carbohydrates in relation to animal nutrition. J. Dairy Sci. 74, 3583-3597.

Wiryawan, K.G., Tangendjaja, B., Suryahadi, I., 2000. Tannin degrading bacteria from Indonesian ruminants. In: Brooker, J.D. (Ed.), Tannins in Livestock and Human Nutrition. ACIAR, Adelaide, Australia, pp. 133-136.

Yousef, E.M., Rouzbehan, Y., 2008. Characterization of Quercus persica, Quercus infectoria and Quercus libani as ruminant feeds. Anim. Feed Sci. Technol. 140, 78-89. 